\title{
Produção e formas de circulação do tema do Descobrimento do Brasil: uma análise de seu percurso e do filme Descobrimento do Brasil (1937), de Humberto Mauro'
}

Eduardo Victorio Morettin

Universidade Paulista

\section{RESUMO}

Este artigo discute a produção e as formas de circulação do tema do Descobrimento do Brasil, tendo em vista a análise do filme Descobrimento do Brasil (1937), de Humberto Mauro. Para tanto, procuramos traçar a maneira pela qual este tema surge no século XIX, acompanhando as discussões colocadas pela historiografia da época. Além disto, examinamos a construção de uma iconografia referente ao assunto, por intermédio das obras de Victor Meirelles e Oscar Pereira da Silva, entre outros. A circulação do tema e de sua representação iconográfica é abordada ainda pela análise dos panoramas do começo do século XX, das imagens nos livros didáticos deste período e do cinema dos primeiros tempos no Brasil. Por fim, procuramos entender como a obra do diretor mineiro dialoga com esta produção, apontando para as especificidades do próprio filme enquanto meio de comunicação.

Palavras-chave: Cinema; Descobrimento do Brasil; Pintura; Livros Didáticos.

\section{ABSTRACT}

This article discusses the production and circulation forms of the Brazilian discovery theme, through the analysis of the film "Descobrimento do Brasil" (1937) from Humberto Mauro. For that, we explore the way this theme appears in the XIX century, following the historiographic discussions of this epoch. Besides, we examine the construction of an iconography related to this subject, through the production of Victor Meirelles and Oscar Pereira da Silva, among others. The circulation of this theme and its iconographic representation is also debated via the analysis of the panoramas from the beginning of XX century, via the images in the didactic books of this time and via the first productions of the Brazilian cinema. Finally, we try to understand how "Descobrimento do Brasil" dialogues with this production, highlighting the specificity of the film itself as a means of communication.

Keywords: Cinema; Brazilian Discovery; Painting; Didactic Books. 
Este artigo se propõe a traçar os percursos que o tema do Descobrimento atravessou no decorrer do século XIX e nas primeiras décadas do século XX, com o objetivo de situarmos, ainda que parcialmente, o quadro de referências dentro do qual o filme Descobrimento do Brasil(1937), de Humberto Mauro, foi pensado. Este quadro é amplo e diversificado, passando pela produção dos principais historiadores dos anos mil e oitocentos e pelas representações iconográficas elaboradas pelos pintores acadêmicos ligados às instituiçõ es de cultura do Império e da nascente República. Tais vínculos tornam-se evidentes numa primeira "vista" da obra do diretor mineiro. Encontramos nos créditos o nome de Afonso de Taunay dentre os colaboradores intelectuais do projeto, o que nos remete a uma determinada tradição historiográfica da qual o então diretor do Museu Paulista fazia parte, e que tinha por núcleo central Francisco Adolfo de Varnhagen, João Capistrano de Abreu e a produção do Instituto Histórico e Geográfico Brasileiro. Além disto, o filme pretendia ser uma visualização da carta do escrivão Pero Vaz de Caminha, o que também pressupõe uma certa leitura e apropriação de um documento cujo histórico convém traçar. Por fim, Descobrimento do Brasil recorre, como fonte de composição de seus planos e suas seqüências, a diversas pinturas, 136 sendo A Primeira Missa no Brasil (1861), de Victor Meirelles, a citação mais clara. O filme de Mauro insere-se, portanto, em uma tradição já estabelecida, sendo apresentado pelos gestores do projeto como seu portador e herdeiro. Percebê-la criticamente implica em descortinar algumas das opções que a obra tinha à sua disposição para dar continuidade ao tema, fornecendo subsídios para que se compreenda melhor a sua especificidade em relação a alguns dos materiais que lhe serviram de suporte.

\section{A CELEBRAÇÃO DO PASSADO MEDIANTE CULTO CÍVICO AOS MORTOS}

João José Reis, em $\mathrm{O}$ cotidiano da morte no Brasil oitocentista ${ }^{2}$, discute a reforma funerária proposta pelo médico Manuel Maurício Rebouças em 1831. Até então, era costume a comunidade enterrar os seus mortos no interior das Igrejas. Esta prática estava vinculada a uma crença de que a alma alcançaria, dessa forma, mais rapidamente o céu, pois o corpo estaria sepultado no portal do Paraíso. Rebouças, em tese defendida na Escola de Medicina de Paris, condenou a tradição funerária existente por vários motivos. Dentre estes, considerava que os gases exalados pelos corpos em decomposição eram prejudiciais à saúde. Defendia, como medida de saneamento público, a transferência dos cemitérios para longe das cidades onde o ar pestilente pudesse ser renovado pelo ambiente 
puro de regiões mais altas. Como diz Reis: "salvar a pele tornava-se mais importante do que salvar a alma"3.

Após uma epidemia do cólera em 1855/1856, que atingiu uma vasta área do Império, a implementação das transformações foi acelerada. Por uma questão de saúde pública, os mortos foram expulsos da cidade dos vivos, fazendo parte agora de mundos estranhos. Esta separação era indicativa também de um esfriamento nas relações das pessoas com o sagrado, indicando e influenciando

(...) mudanças no modo de pensar e sentir. Estava em curso um movimento de secularização da mentalidade da época (...). O surto epidêmico de meados do século XIX serviu como catalisador das mudanças que vinham lentamente trabalhando a mentalidade do século, inclusive no que diz respeito ao modo de morrer".

Em relação à presença desta nova mentalidade na sociedade ilustrada no Brasil, vale destacar um dos pontos da tese de Rebouças. Além das preocupações saneadoras, o médico apontava também para uma outra importante função a ser desempenhada pelo cemitério: a de educar civicamente os povos. Neste novo espaço do cenánio urbano, como relata Reis, "as pessoas encontrariam túmulos monumentais a celebrar cidadãos exemplares que haviam bem servido o país e a humanidade ${ }^{{ }_{5}}$. Naquele momento, portanto, a virtude cívica estava substituindo a devoção religiosa.

Em 1856, a necessidade de se cultuar civicamente os mortos também foi apresentada por Manoel de Araújo Porto-Alegre, em "Iconographia Brazileira”, publicado pela Revista do Instituto Histórico e Geografi co Brasileiro ${ }^{6}$. Esta discussão poderia causar estranheza, a princípio, em um artigo teoricamente dedicado a indicar uma "colleção de imagens", ás quais o autor "juntaria algumas noticias biographicas". No entanto, como veremos, o texto apontava para um trabalho que urgia ser feito, pois esta iconografia estava por se formar. Não havia um referencial simbólico da ainda jovem nação a ser celebrado e perpetuado. Diante deste inquietante cenário, tratava-se de selecionar as personagens dignas de permanecerem imortalizadas pelo pincel ou pela espátula. Seleção que traduzia um duplo esforço: em primeiro lugar, de jogar luz sobre as figuras que se destacaram no passado, redimindo-as do esquecimento ao qual form relegadas; por último, de livrá-las das dissensões acerca de sua ação, presentes no momento em que participavam da luta política, a fim de que pudessem ser cultuadas e tivessem seus feitos projetados para o futuro. 
Nessa discussão, cuja mensagem era dirigida à "mocidade", a História assumia um papel fundamental. Uma estátua, por exemplo, que fosse considerada "producto da adulação ou do fanatismo politico" não conseguiria perpetuar a imagem idealizada de uma personagem do passado. A verdadeira base sobre a qual a homenagem escultória deveria ser construída seria a própria História. Seria ela, portanto, que definiria a galeria dos heróis nacionais. Neste sentido, vale transcrever uma passagem mais longa do autor. Para ele,

Conhecida a biographia de todos os homens salientes de uma épocha, seja qual fôr a sua acção civilizadora, está conhecida a historia d'aquelles tempos; porque nos seus actos, nas suas idéas, nos seus resultados, está o movimento geral, as peripecias do drama animado da sociedade, onde cada um d'estes individuos foi actor e compositor.

Ao despontar de uma grande phase, de uma vida reorganisadora, encontram-se vultos grandiosos, sentinellas que guardam as sagradas avenidas do futuro, e servem de ostensores aos que o tempo vai incorporando na marcha dos acontecimentos?.

Tratava-se, portanto, de delimitar a História pátria, celebrando os seus mortos, recuperando as suas virtudes cívicas e construindo os referenciais documentais de valorização deste passado. Neste processo de construção, um tema, o do Descobrimento do Brasil, possui especial significado, pois remete a uma dupla e complementar fundação: a da nação e a da própria História.

\section{A CONSTRUÇÃO DO TEMA NA HISTORIOGRAFIA} BRASILEIRA DO SÉCULO XIX

Neste percurso, o primeiro passo é lançar as bases sobre as quais esta fundação pode ser rememorada. No caso, estamos nos referindo à recuperação das fontes sobre o tema, que devem ser selecionadas, verificadas em sua autenticidade e trabalhadas pelo profissional competente para que a memória ganhe contornos de história. Neste sentido, é interessante acompanhar a trajetória do documento mais importante sobre 0 assunto, a saber, a Carta a el-rei D. Manoel, escrita deste Porto Seguro de vossa ilha de Vera Cruz, hoje sexta-feira 1ํ de Maio de 1500 , de Pero Vaz de Caminha, escrivão da armada de Pedro Álvares Cabral e testemunha direta do acontecido.

Este documento somente foi disponibilizado para consulta no final do século XVIII quando, em 1773, a carta foi copiada por ordem do guar- 
da-mor da Torre do Tombo. O primeiro historiador a publicá-lo, ainda que parcialmente, foi o castelhano João Baptista Muñoz, em 1790, em His toria del Novo Mundo. A sua primeira edição no Brasil ficou a cargo do padre Manuel Ayres do Casal em sua Corografia Brasílica , de 1817, da qual retirou as passagens referentes à sexualidade. Em 1826 foi publicada na íntegra do documento pela Academia das Ciências de Lisboa. Ainda nos anos 20 daquele século, a carta foi traduzida para o alemão, o francês e o inglês, sendo analisada por Ferdinand Denis e Robert Southey, entre outros. Somente em 1877 preparou-se uma nova edição brasileira, desta vez publicada pela Revista do Instituto Histórico e Geográfico Bra sileiro, Tomo 40, part. 2, "por instancia de Varnhagen", conforme nos informa Capistrano de Abreu. Novas publicações foram preparadas em função de outras comemorações, celebradas nos anos de 1892 e 1900:.

Estas edições permitiriam que o tema viesse a ser lapidado pelos historiadores, que se dedicam a dirimir diversas questõ es sobre o assunto. Por intermédio da Revista do Instituto Histórico e Geográfico Brasileiro, órgão fundado em 1838, muitas polêmicas acerca do Descobrimento serão travadas. Tais discussões, juntamente com os livros de Francisco Adolfo de Varnhagen e de Capistrano de Abreu, possibilitariam a demarcação do tema e a instituição de sua história.

A partir de 1850, Joaquim Norberto de Sousa Silva e Gonçalves Dias iniciam um debate sobre a teoria da casualidade ou não da descoberta, pondo a carta de Caminha em relevo na discussão ${ }^{9}$. Varnhagen e Henrique de Beaurepaire-Rohan procuram definir com precisão o local efetivo do desembarque da armada de Cabral e da realização da primeira missa em território brasileiro ${ }^{10}$.

Um outro problema se colocava para os historiadores da época: 0 dia em que o Brasil foi desco berto. Atualmente, conhecemos e comemoramos o 22 de abril, porém o século XIX celebrava o fato no dia 3 de maio, momento em que, supostamente, a primeira missa no novo território teria sido realizada. É curioso anotar que em 1900 este foi o dia escolhido para darinício às festividades referentes ao quarto centenário ${ }^{11}$. Esta escolha diz muito também sobre o que deve ser comemorado dentro do tema, ao privilegiar a ação de algumas personagens em detrimento de outras, dado que o 3 de maio evocava mais a participação da Igreja no momento de conquista da colônia.

Em suma, o debate historiográfico da época havia levantado e discutido as principais polêmicas por intermédio dos documentos, definindo também os mortos a serem cultuados. Em relação a este último aspec- 
to, no século XIX dispôs às gerações futuras os locais sobre os quais deveriam erguer-se os panteões dedicados ao culto cívico, no quadro de preocupações de Rebouças e Porto-Alegre. Estamos nos referindo ao jazigo de Cabral, encontrado por Varnhagen no ano de 1839 na cidade de Santarém, em Portugal ${ }^{12}$.

\section{Francisco Adolfo de VARNHAgen}

Em 1840, Varnhagen escreveu a obra literária O Descobrimento do Brasil, Crônica do Fim do Século , publicada primeiro em Portugal e depois no Brasil. Segundo Massaud Moisés, a partir da carta de Caminha, o autor relatou "o idílio amoroso fictício entre a índia Ypepa e o navegante Braz Ribeiro" iniciado durante o desembarque de Cabral em nossas terras $^{13}$. Alguns anos mais tarde, Varnhagen substituiu o tratamento literário pelo histórico. $\mathrm{O}$ estatuto que o autor conferiu à História evidencia-se no seu prefácio de História da Independência do Brasil , obra que é posterior à História Geral do Brasil , mas que pode perfeitamente ser utilizada para pensarmos o conjunto de sua produção.Em primeiro lugar, o autor chama a nossa atenção para o correto procedimento do historiador. Para ele, o "historiógrafo",

(...) cumpre com o seu dever quando, com critério e boa-fé e imparcialidade, dá, como em um jurado, mui conscienciosamente o seu veredicto, cotejando os documentos e as informações orais apuradas com o maior escrúpulo que, à custa do seu ardor em investigar a verdade, conseguiu ajuntar ${ }^{4}$.

A crença na boa-fé, na imparcialidade e no veredito final traduzem o espírito cientificista que preside o seu trabalho. É a sua propalada objetividade que distancia suas obras daquelas feitas sobre o assunto até então, que são vistas como "memorandos", justificadoras dos "direitos de uma das partes contendoras". Estes textos são tratados como memórias que devem sofrer a ação de correção feita pelo historiador para que possam ganhar o estatuto de História. Neste sentido, é importante notar o peso que esta palavra ganha em seu texto:

Preciosos como são esses volumes, pecam pela sua insuficiência e falta quase total de redação e de critério; e, mais que uma História, eram importantes apontamentos de decretos e discursos conhecidos e até impressos, próprios para serem depois, como foram, aproveitados e postos em estilo por mais corrente pena, e com muitas adições inteiramente inéditas o serão de novo por nós nesta História $(. . .)^{15}$. 
É interessante notar neste trecho a identidade entre a História-ciência e a História vista como produto do trabalho do profissional competente. No caso de Varnhagen, e não só dele, os dois termos são sinônimos. Só nos resta agora entender como esta equivalência se apresenta na elaboração do tema do descobrimento. Na primeira seção $0^{16}$, 0 autor faz uma descrição geral do Brasil, atendo-se à origem do nome e à apreciação - favorável - de nossa natureza. Nas três seções seguintes, o historiador discome so bre os índios existentes no Brasil. Cabe ressaltar que Varnhagen aponta para uma série de características negativas na formação destes grupo $\mathrm{S}^{17}$. Enxergando o outro pelo que ele não tem (eles não possuem Estado, família, jurisprudência, patriotismo e religião), o historiador constrói o quadro de justificativas necessário para explicar a importância da chegada do homem branco. Além de trazer a civilização, a vinda do europeu salva este território do despovoamento, inevitável devido à tendência à guerra e aos hábitos culturais dos "selvagens". O historiador, tão apegado ao sentimento de verdade e boa-fé, inverte o jogo. Ao invés de o branco ser responsabilizado pelo extermínio dos "selvagens", Varnhagen credita ao modo de vida dos indígenas a responsabilidade pelo seu fim, o que confere aos invasores um papel fundamental: são eles que impedem o despovoamento do imenso território.

(...) e, numa tão grande extensão de território, não aparecia um só chefe que estabelecesse um centro poderoso, como havia no Peru, cuja aristocracia, livre de cuidar só em resguardar-se das intempéries e em adquirir diariamente o necessário alimento, pudesse pensar no bem dos seus semelhantes, apaziguando as suas contendas, e civilizando-os com o exemplo, e servindo-lhes de estímulo, para se distinguirem e procurarem elevar-se. Assim tais rixas perpetuariam neste abençoado solo a anarquia selvagem, ou viriam a deixá-lo sem população, se a Providência Divina não tivesse acudido a dispor que o cristianismo viesse ter mão a tão triste e degradante estado !18.

O mesmo capítulo que trata do Descobrimento da América discute o do Brasil. $O$ autor faz um apanhado geral de todas as teorias que contribuiram para que tanto Portugal como a Espanha buscassem uma nova rota comercial rumo ao Oriente e às suas especiarias. Discute as querelas diplomáticas envolvidas na assinatura do Tratado de Tordesilhas em 1494, cuja importância para o Descobrimento se manifesta pela suspeição de que Portugal soubesse da existência de terras ao sul do meridiano do Equador.

A partir deste ponto, Varnhagen faz a descrição do Descobrimento 
desde a partida da esquadra de Cabral do Rio Tejo a 9 de março de 1500, tendo por base principalmente as informações contidas na carta de Caminha. Entre outras questões, o autor sustenta a teoria da casualidade, não pelo fato de Cabral e seus pilotos terem se desviado acidentalmente de sua rota em direção às Índias e aqui abarcado, após enfrentar as famosas calmarias, mas sim porque o capitão não sabia de antemão o local preciso em que se encontrava o território que viria a ser descoberto. Varnhagen demonstra que, a partir das instruções escritas por Vasco da Gama, a descoberta era questão de tempo e que, se não fosse Cabral, outro navegador a teria encontrado. O autor credita ao descobridor do caminho para as Índias a responsabilidade pelo "achamento" da terra. Afora este ponto polêmico, o historiador também se refere à presença dos espanhóis no Brasil antes do 22 abril, citando as expedições de Alonso de Hojeda, de junho de 1499, a de Vicente Yañez Pinzon e a de Diogo de Lepe ocorridas, respectivamente, em 26 de janeiro e em fevereiro de 1500.

Interessa-nos agora, em virtude de nosso objetivo final de discutir a maneira pela qual se articula o quadro de referências a respeito do tema em Descobrimento do Brasil (1937), de Humberto Mauro, verificar como o autor trabalha a carta do "ingênuo Pero Vaz de Caminha". Varnhagen, 142 além de utilizá-la para reconstituir cronologicamente a descoberta e a estadia aqui da armada de Cabral, reproduz dois trechos inteiros do documento. Esta estratégia - a de colocar em primeiro plano a fonte - é adotada em todo o livro. A intenção é a de deixar as "provas" do fato histórico "falarem" por si. Dentre os dois segmentos selecionados, um diz respeito à recepção dada pelos portugueses aos dois índios que foram trazidos a bordo, que será comentada mais detalhadamente adiante. Varnhagen não explica o porquê de ter selecionado tal passagem, mas, tendo em vista a maneira como considera a chegada do branco no continente americano, podemos deduzir que a escolha tem por função prenunciar o benefício a ser trazido pelos portugueses com a colonização, dada a maneira pacífica pela qual os índios form tratados pelo europeu. De certa forma, esta leitura prevalecerá na apropriação feita pelo filme desta passagem, como veremos. Na outra transcrição feita da carta, Varnhagen seleciona trechos do depoimento do escrivão em que ele descreve as caracteństicas físicas dos nativos. O historiador dedica dois parágrafos às missas realizadas no território. A primeira, ocorrida em um ilhéu na entrada do Porto Seguro em um domingo de Páscoa a 26 de abril, e a segunda, de $1^{0}$ de maio, quando "se efetuou a cerimônia da tomada de posse da nova região para a Coroa de Portugal”"19. Em relação à primeira, observa que predominou o es- 
panto entre os índios que a assistiram, e não a devoção, como alguns portugueses e boa parte da historiografia queriam crer.

\section{CAPISTRANO DE ABREU}

Para Capistrano de Abreu, a obra de Varnhagen representava, em 1882, um ponto de partida. Apesar das insuficiências, o autor havia demonstrado que o trabalho de construção de uma História do Brasil poderia ser considerado iniciado. $\mathrm{O}$ historiador cearense advertia que esta:

(...) não será de novo escripta tão cedo; e pensamos até mais, que ella não deve ser escripta senão daqui a muitos annos. Agora o que se precisa é de monographias conscienciosas ${ }^{20}$.

O caráter monográfico dos obras históricas do final do século XIX e inícios do século XX parece confirmar este reclamo de Abreu, ele mesmo autor de uma série delas sobre, principalmente, o tema do Descobrimento. O primeiro trabalho de Abreu acerca do assunto é Descobrimento do Brasil. Seu desenvolvimento no século XVI tese apresentada em 1883 para o provimento da cadeira de história do Brasil do colégio Pedro $\mathrm{II}^{21}$. Nesta obra, o historiador discute as pretensões francesas, espanholas e portuguesas em relação ao descobrimento da colônia. É importante destacar o seu método. A partir do momento em que se dispõe a examinar estas teorias, Abreu faz um apanhado geral das fontes e da historiografia sobre 0 assunto com o objetivo de atingir, por intermédio de uma metódica bem acurada, o veredito final. Para a análise de cada pretensão e conferência de sua autoridade, o autor inicia a sua apresentação com a indicação das fontes consultadas, dado fundamental dentro de sua estratégia. Compara os documentos, aponta para a contradição interna dos diversos relatos, busca os testemunhos diretos do fato e aquilo que a tradição preservou, verifica a veracidade das fontes utilizadas pelos cronistas e historiadores, reclama da ausência ou da falta de referências precisas das fontes comprobatónias das diversas teorias sobre o passado, e conclui sobre a validade de cada uma delas. Este desfecho é importante, pois significa avaliar aquilo que do ponto de vista histórico pode ser considerado verdadeiro ou não. Quando há dúvidas a respeito da autenticidade de determinada informação, procura estabelecer qual é a mais provável, abstendo-se de julgar improcedente uma afirmação quando os documentos não fornecem dados suficientes para a sua refutação. O mesmo procedimento será 
utilizado para discutir os "pontos controversos", a saber: a teoria da casualidade; o motivo que levou Cabral a dar o nome de Vera Cruz à terra descoberta; a correspondência entre o Porto Seguro atual e o da época de Cabral; o responsável por ter levado a notícia da descoberta ao rei de Portugal.

Em O Descobrimento do Brasil pelos Portuguesesartigo de 03 de maio de 1900 publicado primeiramente no Jornal do Commercio e depois em opúsculo a 4 de maio de $1900^{22}$. Abreu acompanha mais de perto a expedição de Cabral por intermédio, principalmente, da carta de Caminha. D escreve de maneira pormenorizada diversos episódios referentes à viagem. Traz mais informações so bre a expedição e seus participantes, como frei Henrique e Duarte Pacheco, por exemplo. Retoma as questões controversas, introduzindo e esclarecendo novos pontos, como os referentes à autenticidade da carta e à ortografia correta do nome Brasil, além de dedicar mais tempo para o exame da teoria da casualidade. Por fim, ao comentar o encontro ocorrido na África em 1501 entre Cabral, que regressava de Calicute, e Américo Vespucio, apresenta as chamadas "duas correntes históricas". A primeira é representada pelos portugueses, 144 cujo marco inicial foi a conquista de Ceuta, em 1415. A segunda relaciona-se aos espanhóis que, como sabemos, procuraram chegar às Índias pelo Ocidente.

Em O Descobrimento do Brasil. Povoamento do Sólo - Evolução So cial , também de $1900^{23}$, o autor insere a descoberta do país dentro de contexto mais amplo. Fala da expedição de Cabral após um histórico da situação do comércio entre o Oriente e o Ocidente, da expansão marítima portuguesa, das expedições de Colombo, Pinzon e Lepe e das bulas papais que regulamentavam a posse dos novos territórios descobertos. Em relação à expedição, preocupa-o mais entender o fato de os portugueses acreditarem ser o Brasil uma ilha. O historiador interrompe a sua descrição para dedicar um capítulo aos índios, espaço que não fora aberto nos trabalhos anteriores. Digo interrompe, pois o autor retomará a narração da viagem de Cabral a partir do dia 2 de maio, quando a armada se dirige para o cabo da Boa Esperança, e o referido encontro deste navegador com Vespúcio, acrescentando, em relação ao último livro, uma série de dados novos. Abreu desenvolve muitos dos aspectos já trabalhados por Varnhagen em relação aos índios, mas, ao contrário deste historiador, procura descrever sem atribuir a priori um caráter valorativo e preconcebi- 
do. Desta forma, tenta entender as práticas rituais dos indígenas, como vemos a seguir:

Dos prisioneiros feitos, uns ficavam escravos, outros eram devorados. No gosto pela carne humana destacavam-se os Tupis, que faziam o sacrificio com toda a solenidade. Parece, porém, que o sacrifício já adquirira certo caracter symbolico; em logares occupados por inimigos, não tendo a quem matar e comer, desenterravam os mortos e quebravam-lhes o craneo. Não seria este um meio de matar a alma do inimigo, de libertar-se de suas perseguições? ${ }^{24}$.

Em seu último opúsculo sobre o assunto, Vaz de Caminha e sua Carta ${ }^{25}$, texto publicado pela primeira vez em 1908, o autor faz um exame acurado do documento, recuperando a história de suas edições e 0 seu estilo, além de traçar uma biografia de Caminha. Abreu detém-se mais nos momentos em que o escrivão observa os índios, ressaltando o tom favorável aos índios impresso por Caminha em sua carta, cuja "sympathia" aumentou diante da convivência mútua. Note-se que a descrição dos índios tomados por Afonso Lopes é mais uma vez transcrita, como já havia feito Varnhagen. Este dado é importante, pois podemos entender esta reincidência como indício de que esta passagem era tida na época como saborosa ou curiosa, compreendendo também o porquê de sua referência em Descobrimento do Brasil, de Mauro.

\section{O TEMA DO DESCOBRIMENTO NA PINTURA DE HISTÓRIA DO SÉCULO XIX}

Chegamos ao final do século XIX com o tema delimitado pela Histónia. Durante este mesmo peńodo, o "descobrimento" do Brasil também será objeto da arte acadêmica, passível de elaboração e de construção de imagens que se tornaram referenciais também para a História. Como veremos, muitas conexões podem ser estabelecidas entre uma e outra área. Estas serão importantes, mais uma vez lembramos, para entendermos o quadro de referências iconográficas dentro do qual se move o filme de Humberto Mauro.

Em primeiro lugar, é importante discutirmos a presença da História neste gênero, inserido dentro de um estilo de representação artística defendido e amparado pela Academia Imperial de Belas Artes. Um de seus principais expoentes no Brasil foi também aquele que nos deixou uma reflexão mais acabada sobre esta inter-relação. Trata-se de Pedro Améri- 
co, autor de A Batalha de Campo Grande (1872) e Batalha de Avaí (1879), entre outros trabalhos.

Em O Brado do Ypiranga ou a Proclamação da Independencia do Brasil ${ }^{26}$, Américo comenta Independência ou Morte! (1888), obra confeccionada especialmente para o Museu Paulista, e talvez uma das mais conhecidas de seu autoria. Sua labuta se desdobrou em duas frentes: primeiro, na elaboração de uma representação pictórica do tema "independência", configurada no quadro; segundo, na tentativa de justificá-la historicamente, por meio deste pequeno opúsculo.

O pintor divide o seu texto em duas partes: "o fato" e "a pintura". Em relação à parte em que o pintor apresenta os problemas referentes à confecção da tela, Américo alerta sobre as dificuldades existentes para

restaurar mentalmente, e revestir das apparencias materiaes do real, todas as particularidades de um acontecimento que passou-se ha mais de meio seculo; principalmente quando não nos foi elle transmitido por contemporaneos habeis na arte de observar e descrever ${ }^{27}$.

Além do mais, os problemas aumentam quando o artista necessita 146 especificar as circunstâncias sobre as quais se têm dúvidas ou, independente de serem "reaes", dispor de episódios ou informações que não mereceram "a attenção da historia e a consagração do bello". Tendo em vista estes problemas, Américo sustenta que uma pintura histórica deve ancorar-se, enquanto síntese, na verdade histórica e, enquanto análise, nas considerações derivadas de "circumstancias verosimeis e provaveis, e do conhecimento das leis e das convenções da arte".

Nesse sentido, o pintor afirma:

A realidade inspira, e não escraviza o pintor. Inspira-o aquillo que ella encerra digno de ser offerecido á contemplação publica, mas não o escraviza o quanto encobre contrario aos designios da arte, os quaes muitas vezes coincidem com os designios da historia ${ }^{28}$.

A escravização perpetrada pela realidade não deve coagir o artista a buscar sua exata reprodução, na medida em que, por vezes, este trabalho pode diminuir o impacto estético de uma obra. Neste caso, em particular, o que é contrário aos "desígnios da arte" e, por vezes, "da história” deve ser modificado, como, por exemplo, a montaria de D. Pedro e comitiva, a fisionomia do futuro imperador, o uniforme da Guarda de Honra 
e o número de pessoas que acompanharam o fato histórico. O pintor-historiador reclama, exceto nos detalhes acima indicados, total autenticidade para a sua obra, já que o quadro foi "rigorosamente inspirado na realidade" ${ }^{\prime 29}$. Esta vinculação ocorre em virtude dos testemunhos recolhidos pelo autor e do trabalho de historiadores e escritores consultados.

Dentro deste quadro de preocupações é que devemos analisar a pintura de História de Victor Meirelles de Lima. O pintor matriculou-se na Academia Imperial de Belas Artes em 1847, tendo como professores Félix Émile Taunay (Paisagem, Flores e Animais) e Manuel de Araújo PortoAlegre (Pintura Histórica). Em 1852, conseguiu o $7^{0}$ prêmio de Viagem à Europa, concedida pela Academia, desembarcando na Itália no ano seguinte. Permaneceu no continente até 1861, trocando Roma e Milão por Paris no ano de 1856. A estadia de Meirelles na Europa foi acompanhada de perto por Porto-Alegre, principalmente entre 1854 a 1857, período em que foi diretor da Academia Imperial de Belas Artes. A correspondência entre os dois nestes anos foi intensa. Por um lado, esta indica o monitoramento que o Instituto fazia de seus discípulos durante a vigência da bolsa, apontando o que e com quem o pintor estudaria, além dos museus, bibliotecas, liceus e sociedades literárias que deveria frequentar e conhecer $^{30}$. Meirelles, por sua vez, correspondeu às orientações, enviando à Instituição uma grande quantidade de trabalhos, entre estudos, cópias e composições originais, o que contribuiu para a prorrogação de seu estágio por três vezes, até 1860 .

A influência de Porto-Alegre sobre Meirelles continuará após a sua saída da direção do Instituto, como pode ser observado na correspondência trocada entre os dois neste período ${ }^{31}$. Influência que não será apenas de ordem técnica, sugerindo estudos e aprimoramentos, mas também intelectual. Em 1858, uma nova prorrogação da bolsa foi concedida, condicionando-a à confecção de uma grande obra original. Foi de Porto-Alegre a sugestão para que o pintor buscasse inspiração na leitura da carta de Pero Vaz de Caminha, sendo responsável também pela indicação do tema do trabalho a ser realizado, a saber, a primeira missa feita no território na presença dos índios. 0 mesmo Porto-Alegre que em 1856 reclamava da ausência de imagens que representassem nossa história e da falta de apego ao passado por parte das gerações mais jovens, colaborou na construção de um dos mais importantes marcos iconográficos da fundação do Brasil e da pintura de História do século XIX. Seguindo um trajeto similar ao da historiografia, observamos nas artes plásticas do período a 
elaboração e a eleição de um conjunto de referenciais para se entender o nascimento do país. No caso da pintura, trata-se de escolher e selecionar imagens. No entanto, e isto é fundamental, este processo ancora-se na História, como a indicação da carta de Caminha parece ser sufuciente para indicar. Neste sentido, o processo de construção é duplo e com interfaces: da História nasce a Arte e da Arte nasce a História ${ }^{32}$.

Em 1859, o esboceto da obra foi terminado e enviado ao Rio de Janeiro, sendo exposto então. Em 1861, o quadro foi acabado e exibido no Salon de Paris, fato inédito para um artista brasileiro. De acordo com Jorge Coli, o pintor criou um clima de devoção, conduzindo o nosso olhar para o centro, ocupado pela cruz e pelo frei Henrique e seu assistente. Os índios conto mam a cena principal: ao fundo, estão entre a última mata vista no horizonte e os montes, e no primeiro plano, em repouso sob a sombra das árvores. Meirelles deu mais atenção à composição geral da cena e não ao detalhe individual de cada personagem. A preocupação com o equilíbrio está expressa na contraposição claro-escuro que, apesar de criar dois campos distintos, consegue harmonizá-los. Esta consagração da harmonia é importante, pois insere neste momento de fundação os dois elementos tidos como constitutivos da nação: o branco e o índio. 148 Além disso, a natureza nacional está presente em sua exuberância, conforme pedido de Porto-Alegre nesse sentido.

Antes de apresentarmos os outros quadros feitos no século XIX sobre o tema, gostaríamos de tecer alguns comentários sobre a forma pela qual Caminha relata os primeiros contatos entre brancos e índios. Isso é importante porque poderemos entender algumas das opções feitas pelo próprio Meirelles e pelos demais artistas que retrataram este momento, além da seqüência do filme de Mauro em análise. A primeira referência a este contato se encontra no dia 23 de abril. Nicolau Coelho, em expedição de reconhecimento do litoral, avista índios na praia. Segundo Caminha, o "entendimento" não foi de to do possível, "por o mar quebrar na costa", ou seja, por ser o local de difícil desembarque. Apesar das dificuldades, alguns objetos foram trocados ${ }^{33}$. No dia seguinte, a armada muda de local, deslocando-se para o que viria então a ser denominado Porto Seguro. É aí que ocorre o segundo contato. Afonso Lopes é mandado para a terra, "por ser homem vivo e destro para isso".

(...) e tomou 34 dois daqueles homens da terra, mancebos e de bons corpos, que estavam numa almadia. Um dêles trazia um arco e seis ou sete setas; e na praia andavam muitos com seus arcos e setas; mas de nada lhes 
serviram. Trouxe-os logo, já de noite, ao capitão, em cuja nau foram recebidos com muito prazer e festa ${ }^{35}$.

Depois de descrever detalhadamente os índios, passagem citada por Varnhagen e Abreu, Caminha nos conta como viu a recepção feita pelos portugueses dentro do navio. A transcrição desta passagem é fundamental, pois ela ilustra a contraposição destes dois mundos, que pela primeira vez se reúnem nestas paragens. Conforme o escrivão,

O Capitão, quando êles vieram, estava sentado em uma cadeira, bem vestido, com um colar de ouro mui grande ao pescoço, e as pés uma alcatifa por estrado. Sancho de Tovar, Simão de Miranda, Nicolau Coelho, e nós outros que aquí na nau com êle vamos, sentados no chão, pela alcatifa. Acenderam-se tochas. Entraram. Mas não fizeram sinal de cortesia, nem de falar ao Capitão nem a ninguém. Porém um dêles pôs ôlho no colar do Capitão, e começou de acenar com a mão para a terra e depois para o colar, como que nos dizendo que ali havia ouro. Também olhou para um castiçal de prata e assim mesmo acenava para a terra e novamente para o castiçal, como se lá também houvesse prata. (...) Viu um dêles umas contas de rosário, brancas; acenou que lhas dessem, folgou muito com elas, e lançou-as ao pescoço. Depois tirou-as e enrolou-as no braço e acenava para a terra e de novo para as contas e para o colar do Capitão, como dizendo que dariam ouro por aquilo. Isto tomávamos nós assim por assim o desejarmos. Mas se êle queria dizer que levaria as contas e mais o colar, isto não o queríamos nós entender, porque não lho havíamos de dar. E depois tornou as contas a quem lhas dera. Então estiraram-se de costas na alcatifa, a dormir, sem buscarem maneira de encobrir suas vergonhas, as quais não eram fanadas; e as cabeleiras delas estavam bem rapadas e feitas. O Capitão lhes mandou pôr por baixo das cabeças seus coxins; e o da cabeleira esforçava-se por a não quebrar. E lançaram-lhes um manto por cima; e êles consentiram, quedaram-se e dormiram ${ }^{36}$.

Em relação ao encontro ${ }^{37}$, entre outras questões, é importante marcar que tenha sido imposto naquele que é o espaço simbólico de poder do viajante, sendo sintomático o fato de não ter ocorrido em terra. Ao mesmo tempo, o espaço de sua efetivação é disposto de forma hierárquica: de um lado, os representantes da civilização, de outro, os representantes da bárbarie. Ostentam-se diante dos índios aqueles que são considerados os indícios de progresso: a religião (as contas do rosário) e o Estado (o colar do Capitão). Por outro lado, destaque-se a qualidade da comunica- 
ção entre os dois grupos. Ela está sempre associada à interrogação. O índio é visto como objeto de trabalho, informação e correção. Neste sentido, são significativos também os alimentos, os animais e as bebidas que os índios conhecem pela primeira vez, além das "vergonhas" que são por fim cobertas com um manto. Por último, a maneira pela qual os naturais são acolhidos pelos portugueses serviu para configurar o benefício que os índios desfrutariam deste contato:

No dia 25 de abril ocorre o terceiro contato dos portugueses com os índios no território. Cabral envia Nicolau Coelho, Caminha, Bartolomeu Dias, os dois índios que haviam pernoitado na nau e o degredado Afonso Ribeiro, "para lá andar com êles e saber de seu viver e maneiras" ${ }^{\text {38. }}$. Esperavam a pequena comitiva cerca de 200 índios, encontrando-se ao longo da praia. Desembarcaram primeiro os dois índios. O primeiro branco a pisar em nosso território naquele momento foi o degredado ${ }^{39}$. Isto demonstra a função que ele e outros na sua condição tinham na expedição. Em primeiro lugar, serviam de resguardo, pois caso ocorresse algum imprevisto, seriam os primeiros a sofrer as conseqüências. Se não fosse estraçalhado, o degredado poderia participar à expedição os usos e os costumes dos tupiniquins, além de obter informações sobre a terra.

A precaução do branco em relação ao índio é nítida na estratégia montada para o desembarque de Cabral. O primeiro contato do capitão com o território ocorre em um ilhéu próximo ao litoral. O local escolhido é, do ponto de vista militar, seguro, pois

(...) é por toda a parte cercado de água, de sorte que ninguém lá pode ir a não ser de barco ou a nado. Alí folgou êle e todos nós outros, bem uma hora e meia ${ }^{40}$.

No dia 26 de abril, Cabral manda rezar missa naquele ilhéu. Depois de voltar novamente à sua nau, o capitão resolve desembarcar em terra. No momento do desembarque, escolheu-se um rio que deveria ser tomado como zona neutra pelos ocupantes. Depois de muitos portugueses passarem para a outra margem, Cabral fez com que dois homens "o tomassem ao colo", atravessando o rio. Caminha observou que alguns índios se dirigiram até Cabral,

(...) não porque o conhecessem por Senhor, pois me parece que não entendem, nem tomavam disso conhecimento, mas porque a gente nossa passava já para aquém do rio ${ }^{41}$. 
Estabelecido e intensificado o contato, iniciam-se os preparativos para a realização da missa de posse do território, ocorrida no dia $1^{\circ}$ de maio e tematizada por Meirelles. Uma passagem merece ser transcrita, tendo em vista o trabalho do pintor catarinense. Ao se referir às reações dos naturais à celebração, o escrivão faz as seguintes observações:

E quando veio ao Evangelho, que nos erguemos todos em pé, com as mãos levantadas, êles se levantaram conosco e alçaram as mãos, ficando assim, até ser acabado; e então tornaram-se a assentar como nós. E quando levantaram a Deus, que nos pusemos de joelhos, êles se puseram assim todos, como nós estávamos com as mãos levantadas, e em tal maneira sossegados, que, certifico a Vossa Alteza, nos fez muita devoção. (...)

Alguns dêles, por o sol ser grande, quando estávamos comungando, levantaram-se, e outros estiveram e ficaram. Um dêles, homem de cinqüenta ou cinqüenta e cinco anos, continuou alí com aqueles que ficaram. Êsse, estando nós assim, ajuntava estes, que ali ficaram, e ainda chamava outros. E andando assim entre êles falando, lhes acenou com o dedo para o altar e depois apontou o dedo para o Céu, como se lhes dissese alguma coisa de bem; e nós assim o tomámos ${ }^{42}$.

A princípio, poderíamos dizer que Primeira Missa segue, em linhas gerais, as preocupações de Caminha em relação à forma pela qual este evento foi assimilado pelos habitantes da terra. Entre outros elementos, encontramos na tela, logo em primeiro plano, o índio mais velho que aponta para o centro da cena, ou seja, para a celebração da missa. Podemos vê-lo com um de seus braços pousado sobre outro membro de sua tribo, numa postura de quem procura compartilhar o momento "espiritualizado" com os demais. Ao registrá-lo nesta atitude, Meirelles procura ativar a comunhão de interesses indicada pelo escrivão. Utilizando esta estratégia, por exemplo, o artista ressalta o caráter sacro do episódio que, embora presente no documento, ganha em sua tradução imagética uma dimensão totalizante, pois tudo conflui para a aceitação da religião católica no novo território. Apesar de as intenções do autor da Carta convergirem para o mesmo ponto, ele nos permite relativizar o próprio relato. Nesse sentido, é importante destacar a frase "e nós assim o tomámos" final. De maneira lapidar, Caminha indica os limites de seu testemunho. Aquilo que no escrivão surge como indício das dificuldades de comunicação existentes entre os dois grupos - o sentido atribuído ao que foi visto pode ser outro -, emerge no trabalho do pintor limpo de qualquer du- 
biedade, dado que a imagem busca a síntese do que é considerado o sentido maior daquele momento, segundo Pedro Américo.

Com este conjunto de referenciais, chegamos às comemorações do 4ํㅡㄹ Centenário do Descobrimento. A Associação responsável pelas festividades promoveu um concurso para eleger uma pintura referente ao tema. Vence Aurélio de Figueiredo, irmão de Pedro Américo, com Terra, que foi exposto no dia 5 de maio. O quadro apresenta Cabral e Frei Henrique ao centro, mas a ação não contempla apenas os principais responsáveis pela expedição, pois vemos também os marinheiros e demais trabalhadores. Em relação à Primeira Missa, este trabalho apresenta um aspecto menos sacro da conquista, característica que está presente em duas outras obras. Tratam-se de Desembarque de Cabral em Porto Segu ro em 1500 (cerca de 1900) e Nau Capitânea de Cabral (ou Índios à bor do da Capitânea de Cabral) (sem data), ambas de Oscar Pereira da Silva, expostas ainda hoje no Museu Paulista.

Em Desembarque..., vemos muitos índios na praia, enquanto outros chegam pelas matas. Estão correndo, gritando e empunhando as suas lanças em função do estado de excitação em que se encontram. Observamos uma pequena embarcação se aproximando da terra. Nela, vemos os 152 dois índios que haviam pernoitado na nau de Cabral, já vestidos e pedindo para os que se achavam na praia se afastassem e abaixassem o seu arco. Além deles, temos outros portugueses, alguns fortemente armados. No centro da tela, no ponto para onde converge o nosso olhar, estão Cabral e um assistente já em terra, dando início ao entendimento com o índio. Esta tela recria a atmosfera descrita por Caminha em relação ao terceiro contato. No entanto, apesardesta possível aproximação, este trabalho de Pereira da Silva mistura elementos da narrativa do escrivão, ao juntar dois momentos que ocorreram separadamente: primeiro, o episódio referente ao desembarque do degredado; segundo, o do comandante da expedição, como expresso pelo título. Trata-se de duas passagens diferentes. Ao transpô-las para o mesmo episódio, o pintor elide a precaução tomada pelo capitão ao desembarcar no território, bem como a estratégia que adotou para efetivá-la. Já Nau Capitânea... , ao que tudo indica um estudo para uma tela maior que nunca chegou a ser feita, trata do episódio acima descrito, onde dois índios foram postados diante de Cabral e de sua entourage. Nesta pequena obra, que retomaremos adiante, destaca-se o alvoroço dos indígenas diante de um agrupamento passivo de brancos, que aparentam nada reagir diante daquilo que é novo.

De uma maneira geral, estas representaçõ es idealizam o momento 
da chegada dos europeus ao Brasil, ancorando-se na História como elemento justificador e autenticador das imagens escolhidas, conforme 0 pensamento de Pedro Américo. Nestes casos, temos a carta de Caminha sendo utilizada como ponto de partida no processo de elaboração das imagens, não impedindo, obviamente, que modificações e apropriações sejam feitas. Assim, a presença do documento fidedigno e o peso conferido à ciência histórica não garantem que todas estas representações apresentem sempre as mesmas tonalidades. Se em Meirelles, e mesmo em Peres, a ação da Igreja é ponto estruturante do acontecimento, em Figueiredo e em Pereira da Silva um outro elemento ganha relevo: a ação dos representantes do Estado português na conquista material do território. Sinal de novos tempos, marcados pela ascensão do positivismo nos primeiros anos da República?

PANORAMAS, LIVROS DIDÁTICOS E CINEMA: NOVAS DIMENSÕES DA CIRCULAÇÃO DO TEMA E DE SUA ICONOGRAFIA

Além do aspecto material, uma outra questão também se configura como característica daquela ascensão: o da educação cívica das massas. Neste contexto, além destes trabalhos, temos o Panorama da Primeira Missa no Brasil , de Meirelles, do qual resta apenas o seu esboço. Os panoramas surgiram entre o final do século XVIII e início do XIX. Tratavamse de pinturas de grandes dimensões: o de Meirelles sobre o Rio de Janeiro, concluido em 1888 e exibido no Brasil alguns anos depois, tinha 115 metros de comprimento por 15 metros de altura e 36,6 metros de diâmetro. Neste tipo de trabalho, o espectador ficava no centro, observando a pintura cilíndrica e podendo contemplá-la a 360ํgraus. Para tanto, construíam-se enormes rotundas, cobrando-se ingressos. Em resumo, o artista encontrava-se diante de um meio diverso, onde a relação com o público era diferente, apesar de o suporte ainda ser a tela. A respeito dos panoramas de Meirelles, sabemos que a afluência foi grande, sendo composta também por estudantes. De acordo com o pintor,

Quem sabe quantos desses infantis visitantes guardarão tão profunda impressão do que ali observaram, que ainda um dia virão por ele atraídos fazer parte de nossa comunhão nacional? ${ }^{3}$

Segundo Vicente de Paula Araújo, o panorama da Primeira Missa foi aberto ao público em junho de 1900, sendo inaugurado pelo presidente da República. Teve 1159 pagantes no primeiro dia de exposição. Segundo 
A Gazeta de Notícias, de 17 de junho de 1900, o panorama "oferece ao visitante a sensação igual à que poderia ter observado o fato verdadeiro"44.

Três questões podem ser colocadas em relação ao panorama do pintor catarinense. A primeira diz respeito à função educativa destas imagens, tal como enunciada por Meirelles. Este caráter pedagógico terá a sua dimensão simbólica ampliada por intermédio de um outro meio de circulação iconográfica, a saber, o livro didático. No final do século XIX, a pintura de História feita no Brasil encontra um novo veículo de exposição, que dialoga diretamente com os alunos. Circe Bittencourt, ao analisar a presença de imagens neste material, refere-se às reflexões do historiador e autor de diversos livros didáticos Ernest Lavisse que, em 1887, prefaciou desta maneira um de seus livros:

As crianças têm necessidade de ver as cenas históricas para compreender a história. É por esta razão que os livros de história que vos apresento estão repletos de imagens. Desejamos forçar os alunos a fixarem as imagens. Sem diminuir o número de gravuras que existiam no texto, compusemos novas séries delas correspondendo a uma série para cada livro. Cada série é acompanhada de questões que os alunos responderão por escrito, após terem olhado o desenho e feito uma pequena reflexão sobre ele. É o que denominamos de revisão pelas imagens e acreditamos que este trabalho possa desenvolver a inteligência das crianças ao mesmo tempo que sua memória ${ }^{45}$.

Tendo em vista os livros didáticos brasileiros produzidos a partir do século XIX, a autora aborda as características de seu material iconográfico. Aponta para a influência francesa na composição das ilustrações referentes à História Geral ou Universal. No caso da iconografia relacionada à História do Brasil, era necessário criar um outro referencial.

As ilustrações mais comuns sobre o passado da nação foram reproduzidas, por desenhistas ou fotógrafos, de quadros históricos produzidos no final do século XIX. Dessa galeria de arte que os livros didáticos foram os principais divulgadores, dois quadros têm sido os mais reproduzidos desde 0 início do século: 07 de setembro de 1822, de Pedro Américo, e a A Primeira Missa do Brasil, de Vitor Meirelles de Lima ${ }^{46}$.

A força com a qual a memória histórica construída no século XIX acerca do tema do Descobrimento se consolida e se amplia pode ser medida por este último aspecto. Condensando o saber considerado correto sobre a História, e ganhando contornos de verdade, as imagens inseridas nos manuais transformam-se na representação visual do fato, sobre o qual 
não devem pairar dúvidas e muito menos interpretações, dado o caráter impositivo e unívoco do conhecimento transmitido pelo livro didático ${ }^{47}$. É interessante notar como a imagem, polissêmica por excelência, é utilizada aqui de maneira restritiva. Ela está lá, pelo menos na vontade manifesta dos autores e editores do material, não para ser discutida enquanto fonte datada e historicamente produzida, mas sim para confirmar o sentido do texto escrito, traduzindo visualmente uma leitura do passado e amarrando História e Arte à mesma operação: a da redução do tema ao fato.

Além da preocupação com a educação cívica, duas outras questões remetem-nos ao filme Descobrimento do Brasil. Em primeiro lugar, o panorama vincula-se diretamente ao surgimento do cinema. É pensando nesta relação que Vicente de Paula Araújo, em estudo já citado, insere 0 panorama de Meirelles. Angela Miller, tendo em vista um outro contexto cultural, aponta para outros liames. Um aspecto refere-se à constituição dos panoramas enquanto espetáculo, dado que pressupõe o comparecimento massivo da população. Afora isto, existe um determinado tipo de ilusionismo espaço-temporal que será desenvolvido posteriormente pelo cinematógrafo. Porúltimo, estamos diante de uma forma de entretenimento que antecipa o drama, o movimento e o espetáculo épico do cinema dos primeiros tempos ${ }^{48}$. Em segundo lugar, a crítica de A Gazeta de Notí cias recoloca a identidade de propostas entre a Arte e a História, pois a obra artística teria permitido a vivência do fato tal qual ele teria ocorrido.

É interessante observar que Meirelles e o tema do descobrimento estejam presentes neste momento de transição para o cinema. Neste contexto, é importante citar o filme Os Guaranis (1908), produzido pela companhia Photo-Americana ${ }^{49}$. Inspirada no romance de José de Alencar, 0 filme foi feito no circo Spinelli, "uma pantomima tal qual era apresentada no picadeiro", encenada pelo palhaço negro Benjamin ${ }^{50}$, que se pintava de branco para interpretar Peri. De acordo com o Jornal do Brasil , de 7 de setembro de 1908, a pantomima começava "com o deslumbrante prólogo, A Primeira Missa no Brasil ", e terminava "com a esplêndida apoteose A Fuga de Peri com Ceci" ${ }_{51}$. Assim, o tema já não circula apenas pelos espaços da cultura reconhecida enquanto tal pela sociedade, como o das paredes do Museu Nacional de Belas Artes, mas ganha outras dimensões pela aliança de dois meios eminentemente populares, como é o caso do circo e do cinema deste período.

O filme de Mauro insere-se em outro registro, pois, ao contrário dessa produção popular feita em uma época em que o cinema não tinha o estatuto cultural adquirido nas décadas seguintes, Descobrimento do Bra - 
sil faz parte de um projeto que se julga portador da maneira correta de tratar a história cinematograficamente, proporcionando a visualização do fato histórico, tal como dito acima. Ponto de chegada de uma boa parte das questões acima discutidas, a película foi recebida como o melhor filme brasileiro de sua época, conforme vemos em Graciliano Ramos ${ }^{52}$, e exemplo de filme histórico, por colocar o documento (carta de Pero Vaz) em primeiro plano ${ }^{53}$. Esta produção de 1937 foi pensada inicialmente como um curta-metragem sobre a região produtora de cacau na Bahia, que conteria uma reconstituição da descoberta do Brasil ${ }^{54}$. Produzido pelo Instituto de Cacau da Bahia, Descobrimento deixou de lado este aspecto documental, fazendo parte de um projeto mais amplo de discussão acerca das possibilidades do uso do cinema para fins educativos ${ }^{55}$. Para validar a sua inserção no mercado, contou com a colaboração intelectual de pensadores reconhecidos em seu período, como Afonso de Taunay e Edgar Roquette-Pinto, além da participação de Heitor Villa-Lobos, que compôs a música especialmente para o filme. A presença do historiador garantiu que determinadas questõ es, como a teoria da casualidade, em conformidade com o pensamento de Varnhagen e Abreu, fossem "visualizada". Além disso, o trabalho de Mauro mobilizou todos os referenciais iconográficos acima mencionados em uma tentativa complementar de conferir autenticidade à obra ${ }^{56}$. Encontramos referências diretas aos quadros já analisados de Meirelles, Pereira da Silva, Aurélio de Figueiredo e Pedro Peres. Em função dos limites deste artigo, discutiremos uma das seqüências, a saber, a que toma por base a tela Nau Capitânea de Cabral (ou Índios à bordo da Capitânea de Cabral) e o referido trecho da carta do escrivão.

É importante salientar algumas das opções feitas pela narrativa em relação ao testemunho de Caminha. De imediato, percebemos que o aspecto de interrogatório conferido a este encontro pelos portugueses é deixado de lado. Em primeiro lugar, os dois índios entram de livre e espontânea vontade na embarcação de Afonso Lopes, que não emprega nenhuma forma de coação para atingir seu objetivo. Para completar este quadro, Cabral, avisado por Caminha da presença da pequena comitiva, diz exultante: "Que se prepare tudo para recebê-los como hóspedes de honra". Ao entrar no compartimento reservado à recepção, vemos os dois índios caminharem na direção dos membros da esquadra portuguesa. Estabelecido visualmente o espaço onde ocorrerá o contato, o primeiro plano mais próximo corresponde ao olhar dos visitantes. Uma panorâmica permite um melhor reconhecimento de Cabral, sentado à frente, frei 
Henrique e Caminha logo atrás, dentre outros. Este dado é importante, pois toda a seqüência se construirá em torno destas três figuras e dos índios. A narrativa toma emprestado por diversas vezes o olhar do escrivão, por exemplo, para que possamos acompanhar diversas cenas referentes ao encontro. Esta estratégia procura dar veracidade ao discurso fílmico, pois é preciso mostrá-lo no papel de testemunha ocular do fato. No entanto, nem tudo que vemos corresponde ao olhar de Caminha, indicando a presença do narrad or na orquestração dos pontos de vista colocados em cena.

Os índios aproximam-se de Cabral, interessados nas condecorações do comandante. Ao mesmo tempo, apontam para fora, indicando a existência de pedras preciosas no continente. Em resposta a este movimento, Cabral, o frei e Caminha trocam olhares de cumplicidade, certos de que estes gestos correspondem àquilo que de fato buscam: metal precioso. Desta forma, a narrativa indica a contribuição voluntária e ingênua do indígena à empresa de conquista. Ingênua, pois os índios não conseguem apreender o significado deste entreolhar-se, escapando-lhes portanto 0 alcance que as informações dadas possuem. Em um movimento similar à operação de visualização dos fatos tal como operada pelos quadros de Meirelles, a narrativa apaga outras possíveis interpretações. O "isto tomávamos nós assim por assim o desejarmos" e as demais ressalvas feitas por Caminha desaparecem aqui como em outras passagens, reforçando-se a leitura que sugere a harmonização.

Depois desta cena, os "hóspedes" são colocados diante de um papagaio, uma cabra e uma galinha. Frente às gargalhadas dos marinheiros em relação à atitude de medo dos índios, Cabral ordena: "Silêncio!", no que é prontamente obedecido.

Apesar da seriedade do momento, há espaço para a descontração: um dos marinheiros recolhe furtivamente do chão uma das frutas desprezadas pelos índios. Vemos, em primeiro plano, mais de uma mão disputando os restos dos alimentos jogados fora, indicando que as condições de vida talvez não fossem tão fáceis como parecem ser. Sintomaticamente, esta passagem não corresponde ao ponto de vista das personagens que até este momento "comandavam" a ação. Voltamos à cena principal. Em plano americano, Frei Henrique beija o crucifixo, mostrando-o aos índios. A música de Villa-Lobos entra neste instante para acentuar o tipo de integração de culturas desejada pelos portugueses. Após circular de mão em mão, um dos índios devolve a imagem de Cristo pregado na cruz para o franciscano. A iniciação, que não é finalizada neste momento, com- 
pletar-se-á na encenação da Primeira Missa, quando um destes índios beija fervorosamente o crucifixo que antes não fora entendido como elemento de adoração de uma outra religião.

De uma certa forma, esta seqüência apresenta os elementos que estarão presentes na efetiva ocupação do território. Sob a égide da conquista material e espiritual, a narrativa procurou reforçar os elementos que apontam, antes mesmo do desembarque dos portugueses, para a convivência harmônica entre as duas raças. Se nos detivermos no quadro de Pereira da Silva, suporte para a disposição espacial das personagens nesta seqüência, o trato pacífico é indicado na pintura pela ausência de qualquer tipo de preocupação dos marinheiros com a segurança de seu chefe. Vemos pelos menos três marujos armados, mas eles não se encontram em estado de alerta, estando também distantes um do outro: um olha desdenhosamente para fora do navio, um outro acompanha a cena de longe, enquanto um terceiro parece ser o único a manter guarda. Além disso, percebemos que durante o encontro outras personagens estão mais concentradas em seus afazeres diário s, como o grupo que está a puxar uma corda, reforçando a disposição geral do quadro em transmitir a idéia de tranqüilidade que teria permeado este momento. Tranqüilidade quebrada, talvez, pela visível excitação dos índios. O filme, por sua vez, quer reforçar ainda mais este arranjo, encontrando para isto elementos na própria carta. Estamos falando do último momento desta passagem, onde os "hóspedes" dormem na nau capitânea. Na carta, como vimos, o capitão ordena que estes recebam os coxins para colocá-los por baixo das cabeças e um manto, mais para cobrir suas "vergonhas" do que protegê-los das oscilações do tempo.

A última cena desta seqüência inicia-se com os dois índios demonstrando sono. Ambos se deitam e, imediatamente, Cabral, por meio de gestos, pede mais uma vez silêncio, solicitando que todos saiam. Um a um Caminha e o franciscano incluídos - saem vagarosamente de nosso campo de visão, atendendo ao pedido do capitão-mor, que permanece no quadro acompanhado de alguns guardas. A fim de que 0 ambiente se torne mais propício para o bom descanso dos "convidados", o comandante da expedição requer o apagamento das tochas que clareavam o local, ação que nós acompanhamos. Ao final desta operação, voltamos a um espaço diferente. Tal fato se deve a dois motivos: primeiro, porque a luminosidade incide de outra maneira sobre os objetos e as personagens, dando maior ênfase aos índios dormindo tranquilamente no chão e à bandeira de Portugal; segundo, por causa de um significativo "lapso" da obra: 
Frei Henrique, que havia há poucos segundos desaparecido da cena, é reconduzido ao local, permanecendo ao lado de Cabral e da flâmula da Coroa portuguesa.

A presença de Frei Henrique nestes últimos planos estava de certa forma indicada no começo da seqüência. Desde o início, os representantes do Estado e da Igreja neste empreendimento vinham recebendo um destaque especial pela narrativa: avistamo-nos primeiramente pelo olhar dos índios. Posteriormente, constituem o foco de atenção dos nativos, ora em função das condecorações e consequente indicação da existência de ouro, ora para marcar o início do processo de conversão. Dentro desta lógica, a sua ausência representaria uma lacuna difícil de ser preenchida, tendo em vista o papel desempenhado pelo franciscano no desenvolvimento da cena. Ele, juntamente com o comandante, completa o serviço de atendimento diferenciado propalado por Cabral no começo da seqüência, protegendo os indígenas das pertubarções que pudessem atrapalhar o seu sono reconfortador. O capitão-mor coloca alguns travesseiros sob suas cabeças, enquanto Frei Henrique cobre-os com dois mantos. O último plano é a da imagem do religioso abençoando os nativos, tendo ao fundo a bandeira de Portugal.

A falha de continuidade acima mencionada evidencia a presença do narrador de maneira ostensiva, cuja manifestação até então era perceptível na escolha do que tratar, na organização dos pontos de vista e no uso do som. Desta forma, esta presença explicita o sentido de harmonização já comentado atrás e sintetiza as leituras feitas pelos pintores acadêmicos, ao unir a conquista material à espiritual. Desnuda também o caráter de artefato de um discurso que se quer real, cuja aparência é mantida pelo respeito aos padrões do cinema clássico americano, do qual Mauro se aproxima. Esta filiação pressupõe justamente o respeito à continuidade, isto é, à idéia de que os elementos ordenados em um plano devem estar a ele relacionados no plano seguinte, e a sua ausência/modificação/transformação precisam ser previamente explicadas, para que esta aparência de realidade não seja quebrada. Deve-se evitar, portanto, a presença de quaisquer mecanismos que nos lembrem que estamos diante de um filme e não da "realidade".

Cabe por fim destacar o papel que a música de Villa-Lobos tem no interior deste projeto , levando-se em consideração a tradição historio gráfica aqui mobilizada. Se, por um lado, a recorrência à História é usada como expediente para afastar a obra do melodrama ${ }^{57}$, conferindo-lhe 0 aspecto educativo preconizado pelos autores do projeto, por outro, a música 
oferece material para dimensões inéditas, ausentes do relato dos especialistas contratados para conferir autenticidade à produção. Assim, ela não apenas ilustra situações, acentua sentimentos ou reforça em determinados momentos a interpretação, conforme o que se espera habitualmente de uma trilha sonora. No caso deste filme de Mauro, as quatro suítes compostas para Descobrimento sugerem imagens diversas das que estão presentes na Carta, nos livros e nos quadros. A segunda peça, por exemplo, é dividida em três partes: "Impressão Moura", "Adágio Sentimental" e "A cascavel". O adágio é referido da seguinte forma: "Lembrança nostalgica e saudosa dos tripulantes, das suas terras e dos seus entes bem amados ${ }^{\prime \prime 58}$. De fato, esta nostalgia estará no filme, como pode ser observado nas seqüências que tratam da viagem pelo Atlântico. Nelas, Mauro atende a uma outra demanda, criando situações, imagens e seqüências a partir do código musical, mas dentro de um universo no qual se movimenta com desenvoltura: o da melancolia. Nestes momentos, o diretor aproxima-se mais daquele que é um dos principais intuitos do compositor: o de criar ambientes que reflitam os "estados d'alma" dos tripulantes ${ }^{59}$.

Neste sentido, Descobrimento incorpora outros elementos que não colaboram para construir uma imagem tão edificante da empreitada. A já 160 comentada dificuldade de Mauro em trabalhar com o "clímax"60 aparece aqui mais uma vez. Da mesma forma que mostra a partida da esquadra de Cabral em meio a acenos dos índios e dos portugueses, somos levados à cruz fincada no chão do território incorporado para acompanharmos a reação dos três degredados que aqui permaneceram. Este plano constitui um contraponto à tônica de felicidade que emana desta seqüência final, pois os portugueses aqui deixados contemplam com tristeza a impossibilidade de voltarem para sua terra.

Portanto, o filme não se conforma aos padrões pré-estabelecidos pelas artes plásticas, pela História e, talvez, pela música. Em função da especificidade do próprio cinema, novos aportes de significado são trazidos ao tema pelo embaralhamento de todos os referenciais anteriores feito pela mise-en-scène do diretor. Encontramos a produção historiográfica do Instituto Histórico e Geográfico Brasileiro e de seus asso ciados, cristalizada no apego à cientificidade, na síntese do que teria sido aquele momento e na ilustração de algumas das teorias defendidas pelos seus membros, como é o caso, por exemplo, da questão da casualidade, tematizada pelo Descobrimento. Temos também as imagens produzidas pelos acadêmicos do século XIX, origem da composição de tipo tableaux presente na obra, dentro de uma tradição cinematográfica que remonta a O Nasci - 
mento de uma Nação (1915), de D. W. Griffith. Porém, da mesma forma que as pinturas e a historiografia apresentam mudanças de tom no decorrer dos anos, o filme, por alguns dos motivos aqui apresentados, confere ao tema a sua modulação, a sua freqüência, diversa em função do meio/suporte pelo qual ele é representado, e necessariamente outra em virtude da época em que foi feito, independentemente de, ao deste longo processo que percorremos, onde algumas destas tradiçõ es foram inventariadas, cada agente ter buscado em seu respectivo tempo acertar o compasso entre presente e passado, a partir do emblema Estado-Nação.

Pensar a produção e as formas de circulação do tema do descobrimento constitui passo fundamental para definirmos os projetos que se encontram na gênese de Descobrimento, estabelecendo os devidos diálogos entre a obra e o seu contexto No entanto, o cinema não deve ser considerado apenas como o ponto de cristalização de um determinado percurso, repositório inerte de várias confluências, sendo o filmico antecipado pela pesquisa erudita. É necessário levar em consideração o que Serge Daney chama de "enigma inicial" ${ }^{11}$ do cinema, ou seja, aquilo que se encontra presente na articulação dos elementos visuais e sonoros, cujo significado emerge por meio de sua análise. Este exame, conforme a obra de Mauro elucida, demonstra a importância da relação entre a imagem e o som quando pensamos as interfaces entre história, ficção e divulgação por meio do cinema.

\section{NOTAS}

${ }^{1}$ Este artigo é uma versão ampliada do trabalho que apresentei no II Colóquio Portugal, Brasil: Quem Fomos? Quem Somos?, no Instituto Superior de Psicologia Aplicada, em março de 2000, na cidade de Lisboa. Agradeço ao Prof. Dr. Ismail Xavier, meu orientador, pela leitura e comentários. Sou grato também a Claudio Aguiar Almeida pelo empréstimo de materiais.

${ }^{2}$ Cf. ALENCASTRO, Luiz Felipe (org.). História da vida privada no Brasil: Império . São Paulo, Companhia das Letras, 1997, pp. 95-141.

${ }^{3}$ Idem, p. 135.

${ }^{4}$ Idem, p. 141.

${ }^{5}$ Idem, p. 134.

${ }^{6} 3^{0}$ trimestre de 1856, tomo XIX (Tomo VI da Terceira Série), no 23, pp. 349-354.

${ }^{7}$ PORTO-ALEGRE. op. cit., p. 353.

${ }^{8}$ Informações retiradas de: ABREU, João Capistrano de. “Vaz de Caminha e sua Carta”. In Des cobrimento do Brasil, s.l.p, Sociedade Capistrano de Abreu, 1929, texto original de 1908, p. 288; VARNHAGEN, Francisco Adolfo de. Histónia geral do Brasil . 10ª ed. integral, Belo Horizonte/São Paulo, Ed. Itatiaia/Edusp, 1981, em nota de Capistrano de Abreu à p. 78; e COL, 
Jorge, "Primeira Missa e Invenção da Descoberta". In NOVAES, Adauto (org.). A descoberta do homem e do mundo, São Paulo, Minc-Funarte/Companhia das Letras, 1998, p. 108.

${ }^{9}$ A este respeito ver SILVA, Joaquim Norberto de Sousa. "O descobrimento do Brasil por Pedro Alvares Cabral foi devido a um mero acaso ou teve elle alguns indicios para isto?". In Revista do Instituto Histórico e Geográfico Brasileiro, 1852, XV, pp. 125-209, e DIAS, Gonçalves, "Reflexões acerca da "Memoria do illustre membro o Sr. Joaquim Norberto de Souza e Silva”. In Revista do Instituto Histórico e Geográfico Brasileiro, 1855, XVIII, pp. 289-334.

${ }^{10}$ Ver VARNHAGEN. "Nota ácerca de como não foi na Corôa Vermelha, na enseada de Santa Cruz, que Cabral primeiro desembarcou e fez dizer a primeira missa”. In Revista do Institu to Histórico e Geográfico Brasileiro, 1877, XL, n. 55, pp. 05-37, e BEAUREPAIRE-ROHAN, Henrique de, "O primitivo e o actual Porto Seguro". In Revista do Instituto Histórico e Geo gráfico Brasileiro , 1880, XLIII, nº 61, pp. 05-26.

${ }^{11}$ Cf. Livro do centenário (1500-1900). Vol. 4, Memoria Historica dos Trabalhos da Asso ciação do Quarto Centenário do Descobrimento do Brasil pelo Dr. Benjamin Franklin Ra miz Galvão. Rio de Janeiro, Imprensa nacional, 1910, p. 165 e seguintes.

${ }^{12}$ Esta notícia foi publicada pela Revista do Instituto Histórico e Geográfico Brasileiro, em seu tomo II, p. 139, cuja referência foi retirada do índice da revista referente aos anos de 1839-1921.

${ }^{13}$ MOISÉS, Massaud. História da Literatura Brasileira. Romantismo, Realismo. volume II , São Paulo, Edusp/Cultrix, 1984, pp. 62-63. As reflexões feitas neste artigo sobre a historiografia brasileira e a pintura de História do século XIX devem muito às discussões realizadas no curso de pós-graduação oferecido em 1997 pela Prof. Dra. Cecília Helena de Salles Oli162 veira no Departamento da História da USP e intitulado “Política e Memória - o Imaginário da Independência".

${ }^{14}$ VARNHAGEN, Francisco Adolfo de. História da Independência do Brasil. 7ạ ed., Belo Horizonte/São Paulo, Ed. Itatiaia/Edusp, 1981, p. 11.

${ }^{15}$ Idem, p. 12, a primeira História é grifada pelo autor.

${ }^{16}$ Conforme Nilo Odália, a primeira edição do livro, de 1854, trazia em seu início capítulos dedicados à história de Portugal. Em função das críticas recebidas, o autor resolveu retirar estas seções, configurando o seu trabalho tal qual o conhecemos hoje (Cf. Vamhagen:his tória. São Paulo, Ática, 1979, p. 19).

${ }^{17}$ Cf. VARNHAGEN, Francisco Adolfo de, História Geral do Brasil , pp. 24; 29; 44-46, principalmente. José Veríssimo anota a especifidade de Varnhagen dentro do período inicial do romantismo. Para ele, o historiador "é talvez o único que além de não ser indianista, isto é, de não ter nenhuma simpatia pelo índio como fator da nossa gente, ao contrário o menospreza, o deprime e até lhe aplaude a destruição" (História da Literatura Brasileira. 5a ed., Rio de Janeiro, Livraria José Olympio Editora, s/d., p. 154)

${ }^{18}$ VARNHAGEN, Francisco Adolfo de. op. cit, pp. 29-30, grifos nossos.

${ }^{19}$ Idem, p. 70.

20 "Sobre o Visconde de Porto Seguro". In Ensaios e Estudos (crítica e história) . s.l.p., Sociedade Capistrano de Abreu/Livraria Briguiet, vol. 1, 1931, p. 204.

${ }^{21}$ Cf. Descobrimento do Brasil, op. cit., pp. 09-136.

${ }^{22}$ ABREU, Capistrano de. Descobrimento do Brasil, op. cit., pp. 137-188. 
${ }^{23}$ Idem, pp. 189-286.

${ }^{24}$ Idem, pp. 254.

${ }^{25}$ ABREU, Capistrano de. op. cit., pp. 287-307.

${ }^{26}$ Algumas palavras acerca do facto historico e do quadro que o commemora pelo Dr. Pe dro Americo de Figueiredo, Florença, Typographia da Arte della Stampa, 1888. Este texto foi reeditado no trabalho organizado por OLIVEIRA, Cecília Helena de Salles e MATTOS, Claudia Valladão de (orgs.). O Brado do Ipiranga , São Paulo, Edusp/Museu Paulista, 1999, pp. 11-35.

${ }^{27}$ MELO, Pedro Américo de Figueiredo. op. cit., p. 13.

${ }^{28}$ Idem, p. 14, gfo. aut.

${ }^{29}$ Idem, p. 17.

${ }^{30}$ Cf. ROSA, Ângelo de Proença e PEIXOTO, Elza Ramos. "Biografia”. In ROSA, Ângelo de Proença et al. Victor Meirelles de Lima: 1832-1903 . Rio de Janeiro, Ed. Pinakotheke, 1982, p. 31.

${ }^{31}$ Idem, p. 41 e MELLORJR., Donato., "Temas Históricos". In ROSA, Ângelo de Proença et al. op. cit, p. 59 e seguintes.

${ }^{32}$ Cf. COL, Jorge. op. cit., p. 111

${ }^{33} \mathrm{O}$ texto por nó s trabalhado é o editado por CORTESÃO, Jaime. "A carta de Pero Vaz de Caminha - Adaptação à linguagem atual”. In A carta de Pero Vaz de Caminha , Rio de Janeiro, Livros de Portugal Ltda, s.d., pp. 193-241. Esta referência encontra-se na página 202.

${ }^{34}$ Para GIUCCI, Guillermo em "A visão inaugural do Brasil: a Terra de Vera Cruz". In Revista Brasileira de História , set. 90/ fev. 91, v. 11, n. 21, p. 55, tomar é aqui um eufemismo para indicar seqüestro e aprisionamento.

${ }^{35}$ CORTESÃO, Jaime. op. cit., p. 204.

${ }^{36}$ Idem, pp. 205-207. A parte suprimida deste relato se refere à reação que os índios tiveram aos animais (papagaio pardo, carneiro e galinha) que lhes foram mostrados e aos alimentos e às bebidas oferecidas.

${ }^{37}$ Boa parte destas e de outras reflexões foram retiradas e/ou inspiradas pelo trabalho já citado de Guillermo Giucci.

${ }^{38}$ CORTESÃO, Jaime. op. cit., p. 208.

${ }^{39}$ Conforme diz Caminha, "Aqueles que nós levávamos acenaram-lhes que se afastassem e poisassem os arcos; e êles os poisaram, mas não se afastaram muito. E mal poisaram os arcos, logo saíram os que nós levávamos, e o mancebo degredado com êles" (Cf. CORTESÃO, Jaime. op. cit, pp. 208-209)

${ }^{40}$ CORTESÃO, Jaime. op. cit., p. 212.

${ }^{41}$ Idem, p. 218.

${ }^{42}$ Idem, pp. 236-237.

${ }^{43}$ Citado por PEIXOTO, Elza. "Panoramas". In ROSA, Ângelo de Proença et al. op.cit., p. 109. As referências às dimensões do panorama sobre o Rio de Janeiro se encontram na página 108. É interessante observar que o pintorjá não se encontrava vinculado à Escola Nacional 
de Belas Artes, nome dado pela República para a antiga Academia Imperial. O trabalho com panoramas se tornou para Meirelles uma de suas fontes de renda.

${ }^{44}$ Citado por ARAÚJO, Vicente de Paula em A Bela Época do Cinema Brasileiro . 2 ${ }^{\mathrm{a}}$ ed., São Paulo, Perspectiva, 1985, p. 36.

${ }^{45}$ Citado por BITTENCOURT, Circe, "Livros didáticos entre textos e imagens". In BITTENCOURT, Circe (org.). O saber histórico na sala de aula. Sâo Paulo, Contexto, 1997, p. 75.

${ }^{46}$ Idem, p. 77.

${ }^{47}$ Sobre esta questão ver VESENTINI, Carlos Alberto, A teia do fato. Uma proposta de estudo sobre a Memória Histórica. São Paulo, Editora Hucitec/História Social, USP, 1997, pp. 65-72, principalmente.

${ }^{48}$ A respeito desta relação ver MILLER, Angela, "The Panorama, the Cinema, and the Emergence of the Spectacular". In Wide Angle, vol. 18, no 2, april 1996, p. 38.

${ }^{49}$ Cf. Guia de Filmes Produzidos no Brasil entre 1897 e 1910 , Rio de Janeiro, Embrafilme, 1984, p. 31.

${ }^{50}$ ARAÚJO, Vicente de Paula, op. cit., p. 264.

${ }^{51}$ Cf. Guia de Filmes..., op. cit., p. 31.

52 “Uma tradução de Pero Vaz". In VIANY, Alex (org.). Humberto Mauro: sua vida, sua arte, sua trajetória no cinema . Rio de Janeiro, Artenova/Embrafilme, 1978, p. 67. Apesar desta consideração, o autor critica duramente a maneira pela qual o filme apresenta o encontro entre índios e brancos.

$164{ }^{53}$ ARAÚJO, Roberto Assunção. O Cinema Sonoro e a Educação (tese) , p. 35. Retomando uma classificação proposta pelo autor, em Descobrimento teríamos os próprios acontecimentos históricos como protagonistas, "com ação mais importante do que as figuras humanas".

${ }^{54}$ Cf. Sem autor, "Cinema Brasileiro”, Cinearte, 1 de agosto de 1936, no 444, p. 10.

${ }^{55}$ Sobre o projeto de cinema educativo e as produções de filmes históricos na primeira metade do século ver MORETTIN, Eduardo. "A representação da história no cinema brasileiro (1907-1949)". In Anais do Museu Paulista: História e Cultura Material , jan./ dez. 1997, Nova Série, vol. 05, pp. 249-271.

${ }^{56}$ Sobre a utilização de pinturas como estratégia de autentificação da História pelo cinema ver MORETTIN, Eduardo, "Quadros em movimento: o uso das fontes iconográficas no filme 'Os Bandeirantes' (1940), de Humberto Mauro”. In Revista Brasileira de História. Dos siê: Arte e Linguagens. 1998, vol. 18, no 35, pp. 105-131.

${ }^{57}$ E não foram poucos os que observaram como aspecto negativo do filme esta separação, a começar por um dos orientadores de Descobrimento, frei Pedro Sinzig. Em crítica publicada no Jornal do Brasil , o religioso observa: “(...) nota-se, com pesar, a ausência de um drama que, desde o início, aumente a ansiedade de espectador pelo desenrolar das cênas. Houve a preocupação (...) de dar cênas rigorosamente historicas." ("O Descobrimento do Brasil", 5 de dezembro de 1937, Suplemento Dominical, p.07).

${ }^{58}$ Sem título. Pasta Correspondência: Cartas a Heitor Villa-Lobos (Museu Villa-Lobos 80.17A.37E)

${ }^{59}$ H. Villa-Lobos. Descobrimento do Brasil (1 ${ }^{\underline{a}}$ suite). Rio, 1937 (documento mimeografado, Museu Villa-Lobos). 
${ }^{60}$ Paulo Emílio Salles Gomes, Humberto Mauro, Cataguases, Cinearte , São Paulo, Perspectiva/Edusp, 1974, pp. 243-244.

${ }^{61}$ Citado por DELAGE, Christian. “Cinéma, Histoire. La réappropriation des récits”. In Verti go. Le cinéma face à l’histoire. 1997, no 16, p. 14. O tom da fala de Daney é de crítica à chamada "escola Ferro". 